J. Perinat. Med. 6 (1978) 28

\section{Determination of fetal maturity from the measurement of the sedimen- tary fraction of the amniotic fluid (amniocrit)}

C. Vera-Medrano, J. Ramirez, G. Canovas, G. Aguad, S. Zuleta, S. Pescio, C. Weber,

R. Gonzalez, F. Zapata

Department of Obstetrics and Gynecology, Regional Hospital of La Serena, La Serena, Chile
In 1915 FABRE [4] described how the amniotic fluid, clear and transparent in the first months, changed its aspect toward the end of gestation, taking on a milky appearance, presenting white clots in suspension. This characteristic of the amniotic fluid led CASTRO and his collaborators [2] to attempt a classification of four types, based on a subjective assessment of the turbidity and the number of particles in suspension. The amniotic fluid of type I was clear and without clots; type II had a few clots in suspension, type III had abundant larger clots, and type IV was filar and viscous. On correlating these types with gestational age they showed that at less than 34 weeks types III and IV do not occur, and that 75 per cent are ot type I. Nonetheless, a determination of the type remained the personal interpretation of each obstetrician, which is a factor impeding comparison.

In an attempt to quantify this parameter to investigate its possible application in the diagnosis of fetal maturity, the sedimentary volume of the amniotic fluid was measured.

\section{Material and methods}

The procedure was to measure the volume of sediment in amniotic fluid obtained from 160 amniocenteses done in high risk pregnancies between 28 and 42 weeks of amenorrhea. The only samples considered for analysis were those (90) that were

\section{Curriculum vitae}

CESAR VERA-MEDRANO was born in Antofagasta (Chile) in 1943. He graduated M.D. in 1967 at the Universidad de Chile, Santiago, who awarded him a fellowship forspecialization in embryology and obstetrics from 1967 to 1970. He was awarded a fellowship at the Laboratory of Research in Human Reproduction (Director Prof. $\mathrm{H}$. ALVAREZ), in Monte-

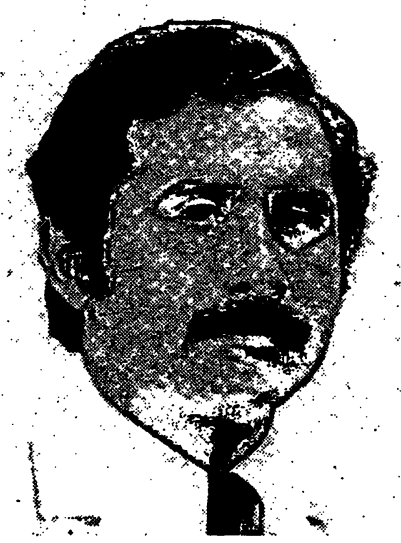
video, Uruguay, in 1970, and then from 1971 to 1973 worked in the Obstetrics Department of the Barros LucoTrudeau Hospital (Santiago, Chile) as coordinator of the high risk obstetrics section, and since 1974 at the Regional Hospital of La Serena (Chile).

clear and without contamination by meconium or blood. Generally $20 \mathrm{ml}$ of liquid were extracted, preferably by suprapubic puncture, and placed in tubes protected from light. Before taking an aliquot for centrifugation each sample was lightly agitated to ensure that it was homogeneous. The sedimentation was carried out in a SHEVKY-STAFFORD tube $^{1}$, placed horizontally, at 3000 r.p.m., for 30 minutes. The centrifuge volume was $6.5 \mathrm{ml}$, and

\footnotetext{
1 ARThUR H. ThOMAS, Co. Catalog No. 2598-G15, P.O.Box-779, Philadelphia, Pa.19105 (U.S.A.)
} 
the resulting sediment was expressed as percent of the total volume. Carried out concurrently were the foam test (after CLEMENTS), determination of creatinine concentration, spectrophotometry, and a count of orange cells stained with Nile Blue sulfate.

\section{Results}

The sediment volume of the amniotic fluid increases progressively in the course of gestation, but more rapidly after 37 weeks of amenorrhea. Prior to that time the sedimentary fraction is always less than 0.7 percent. The mean at 36 weeks is 0.33 percent. At 38 weeks of amenorrhea the mean is greater than 1.0 percent, rising to greater than 2.0 percent at 40 weeks (Tab. I).
The close correlation between gestation age and the fraction of sediment in amniotic fluid is shown in Fig. 1 (correlation coefficient $=0.726$; average uniformity $=0.029 ;$ slope $=0.2989$; intercept $=$ - 10.104). At 41 weeks no values less than 1.10

Tab. I. Arithmetic means of the sedimentary fraction of the amniotic fluid at different weeks of amenorrhea.

\begin{tabular}{llll}
\hline $\begin{array}{l}\text { Week of } \\
\text { amenorrhea }\end{array}$ & $\begin{array}{l}\text { Sedimentary } \\
\text { fraction } \\
\text { (mean) }\end{array}$ & $\begin{array}{l}\text { Standard } \\
\text { deviation }\end{array}$ & $\begin{array}{l}\text { Number of } \\
\text { cases }\end{array}$ \\
\hline 32 & 0.05 & 0.032 & 4 \\
34 & 0.20 & 0.161 & 8 \\
35 & 0.37 & 0.261 & 7 \\
36 & 0.33 & 0.200 & 10 \\
37 & 0.75 & 0.39 & 16 \\
38 & 1.14 & 0.75 & 16 \\
39 & 1.61 & 0.88 & 25 \\
40 & 2.22 & 1.03 & 6 \\
41 & 2.14 & 0.77 & 8 \\
\hline
\end{tabular}

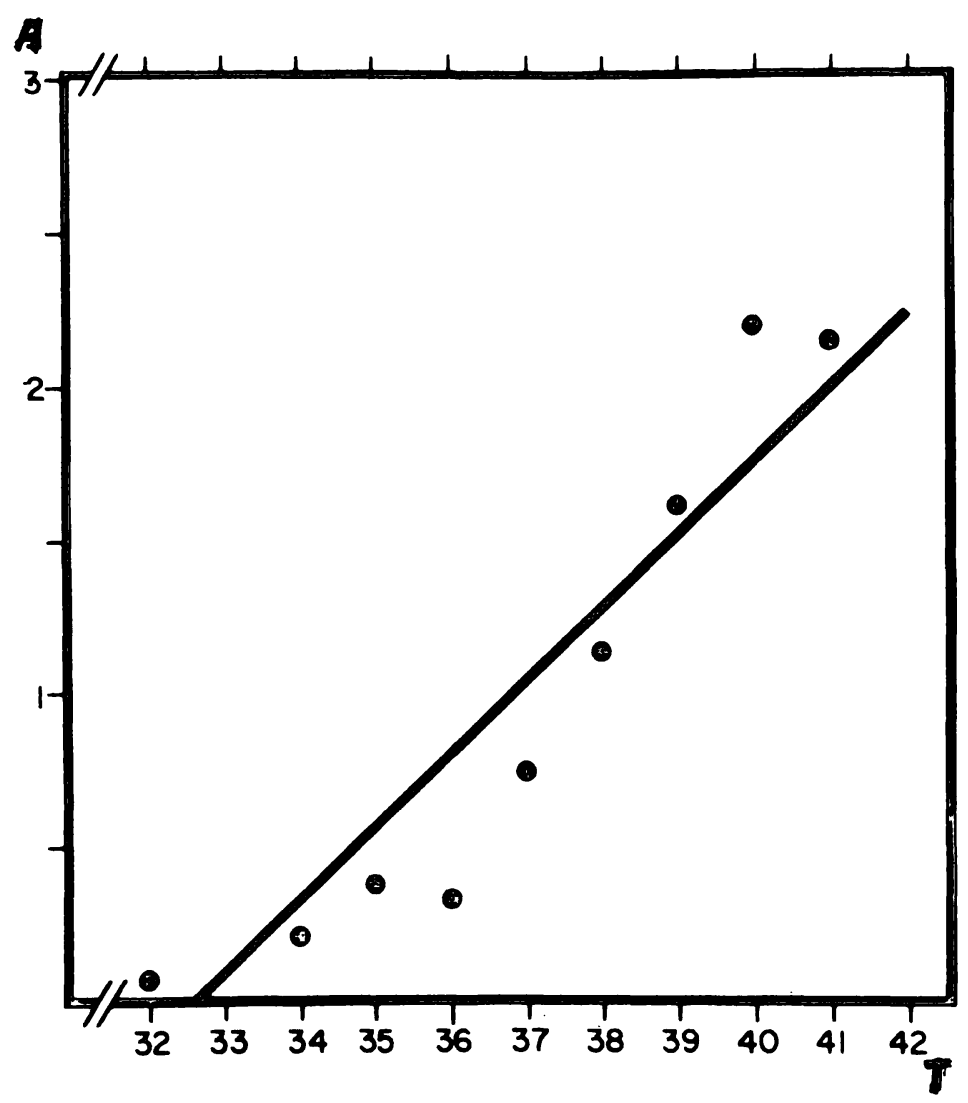

Fig. 1. The correlation is shown between the sedimentary fraction of the amniotic fluid and gestation age from 32 to 41 weeks. Represented are the weekly averaged derived from 90 cases, as well as the best fit for a linear regression represented by the formula:

A: Amniocrit

$T$ : Gestagional age

Amniocrit $=-10.104+0.2989 \mathrm{~T}, 32 \leqslant \mathrm{~T} \leqslant 41$ weeks.

$$
\mathrm{r}=0.726
$$


Tab. II. Comparison of amniocrit value between pre-term and term-pregnancies.

\begin{tabular}{lcc}
\hline & \multicolumn{2}{c}{ Weeks of amenorrhea } \\
\hline & $32-36$ & $37-41$ \\
\cline { 2 - 3 } Number of cases & 29 & 61 \\
Mean value & 0.27 & 1.45 \\
Standard deviation & 0.20 & 0.94 \\
\cline { 2 - 3 } & \multicolumn{2}{c}{$\mathrm{P}<0.001$} \\
\hline
\end{tabular}

are found. A comparison of mean values of preterm pregnancies with those of term pregnancies are found to be significant at the level of $P<0.001$ (Tab. II).

\section{Discussion}

Despite earlier recognition of the change in the optical character of the amniotic fluid during gestation, even the most extensive reviews of the subject reveal no particular mention of the importance that this fact may bear on the estimation of foetal maturity $[3,5,6]$. Although it has been noted that at term the amniotic fluid contains between 1 and 2 percent of solid matter [1] the way in which this fraction varies with gestational age has not been mentioned.

The Hospital Regional de La Serena (Chile) has limited resources, which has motivated our search for costeffective techniques in the diagnosis of foetal maturity. The technique of measuring the sediment combines both simplicity and reliability and can be employed in places with minimal resources.

The utilization of a tube that permits the direct reading of the sediment within the range of interest should be noted. In this sense the SHEvKYSTAFFORD tube is superior to others employed in centrifuge applications, including those for hemocrit. Thus expression of the sedimentary volume of the amniotic fluid in percent has been designated amniocrit.

\section{Summary}

A simple technique is described for evaluating foetal maturity. This consists in measuring the sedimentary fraction of the amniotic fluid (amniocrit).

The amount of sediment, expressed in percent of the total liquid volume varies between $0.33 \%$ at 36 weeks of amenorrhea and about $2.22 \%$ at 40 weeks. These values are correspond to arithmetical means. The differences between pre-term and term pregnancy are highly significant $(\mathrm{p}<0.001)$. The mean at $32-36$ weeks of amenorrhea is 0.27 , and at $37-41$ weeks is 1.45 . A close correlation between gestational age and the fraction of sediment in amniotic fluid is shown in Fig. 1. The correlation coefficient was 0.726 .

This technique of measuring the sediment combines simplicity and reliability and can be employed where minimal resources are available, and in rural hospitals. The feasibility of using this procedure in institutions with limited resources is emphasized.

Keywords: Amniocrit, amniotic fluid, foetal maturity, gestational age, pre-term pregnancy, term prègnancy.

\section{Zusammenfassung}

Bestimmung der fetalen Reife durch Messung der Fruchtwasser-Sedimentation (Amniocrit).

Es wird über eine einfache Technik zur Bestimmung der fetalen Reife berichtet. Die Methodik besteht in der Bestimmung des Fruchtwassersedimentes (Amniocrit).

Die Menge des Sedimentes, ausgedrückt in Prozent des gesamten Flüssigkeitsvolumens, schwankt zwischen $0,33 \%$ in der 36 . und $2,22 \%$ in der 40 . Schwangerschaftswoche. Diese Werte entsprechen den arithmetischen Mittelwerten. Die Differenz der Werte zwischen reifen und noch unreifen Schwangerschaften ist statistisch hochsignifikant $(p<0,001)$. Das arithmetische Mittel für die 32.-36.
Amenorrhoewoche beträgt 0,27 , und der Wert für die 37. -41 . Woche 1,45 .

In Abb. 1 ist die enge Korrelation zwischen Gestationsalter und Amniocrit wiedergegeben. Der Korrelationskoeffizient beträgt 0,726 .

Diese Technik der Sedimentbestimmung vereinigt in sich Zuverlässigkeit und Einfachheit und kann dort angewandt werden, wo ein Minimum an Hilfsmitteln verfügbar ist, nämlich in kleineren Kliniken. Es wird besonderer Wert auf die Einsatzmöglichkeit dieser Methodik in Krankenhäusern mit begrenzten Labormöglichkeiten gelegt.

Schlüsselwörter: Amniocrit, fetale Reife, Fruchtwasser, Gestationsalter, nicht termingerechte Schwangerschaft, termingerechte Schwangerschaft. 
Résumé

Détermination de la maturité foetale par la mesure de la fraction sedimentaire du liquide amniotique (amniocrite)

L'article présent porte sur la description d'une simple technique d'évaluation de la maturité foetale. Ce procédé consiste à mesurer la fraction sédimentaire du liquide amniotique (amniocrite).

La quantité de sédiment, exprimée on pourcentage du volume liquide total, varie entre $0.33 \%$ à 36 semaines d'aménorrhée et environ $2.22 \%$ a 40 semaines. Ces valeurs correspondentaux moyennes arithmétiques. Les différences entre les grossesses à pré-terme ct à terme sont très grandes (p $<0.001$ ). La moyenne arithmétique pour $32-36$ Semaines d'aménorrhée est de 0.27 et la valeur pour 37-41 semaines d'aménorrhée est de 1.45.

Une corrélation étroite entre l'âge de gestation et la fraction de sédiment dans le liquide amniotique est illustrée fig. 1 , le coéfficient de corrélation étant de 0.726 .

Cette technique de mesure sédimentaire est à la fois simple et sûre et peut être employée avec des moyens minimes et dans les hôpitaux des campagnes. On insiste tout particulièrement sur la possibilité d'employer cette méthode dans les instituts aux ressources limitées.

Mots-clés: Age de gestation, amniocrite, grossesse à pré-terme, grossesse à terme, liquide amniotique, maturité foetale.

Acknowledgements: We wish to thank Dr. W. L. Benedetti from the Latin American Center of Perinatology (PAHO/ WHO) for his interest and cooperation. Our thanks also to Professor William Kunkel, from The Interamerican Observatory of Cerro Tololo (AURA), for translation, drawing and scientific cooperation and to Dr. Fernando Lira, for amniotic fluid sample extraction.

\section{Bibliography}

[1] BONSNES, R. W.: Composition of amniotic fluid. Clin. Obstet. Gynec. 9 (1966) 440

[2] CASTRO, F., R. SAEZ, R. RIVEROS, R. SAELZER, J. L. AlCALDE, J. BALMACEDA, E. GUILOFF, J. HASBUN, R. HESS, A. IBARRA, L. MARTINEZ, C. SCHNAPP, A. VALDES, R. WILD, F. ZEGERS, C. GOMES-ROGERS: Determinación de la edad gestacional mediante un sistema de puntaje aplicado a cuatro variables elegidas del líquido amniótico. Rev. Chi. Obst. Ginec. 40 (1975) 105

[3] DORAN, T. A., R. J. BENZIE, J. L. HARKINS, V. M. JONES, C. J. PORTER, D. W. THOMPSON,
S. I. LIEDGREN: Amniotic fluid tests for foetal maturity. Amer. J. Obst. Gynec. 119 (1974) 829

[4] FABRE, P.: Precis d'Obstetrique. J. B. Bailliere, Paris (1915) 21, 2nd Ed.

[5] OSTERGARD, R. R.: The physiology and clinical importance of amniotic fluid. Rev. Obst. Gynec. Survey 25 (1970) 297

[6] PERKINS, R. P.: Antenatal assessment of foetal maturity. Obstet. Gynec. Survey 29 (1974) 369

Received April 3, 1977. Accepted April 30, 1977.

Dr. Cesar Vera-Medrano
Departamento de Obstetricia y Ginecología
Hospital Regional
La Serena, Chile, South America.

Dr. Cesar Vera-Medrano Hospital Regional

La Serena, Chile, South America. 